dementia in general to any substantial extent. If anything, persistent smoking may increase rather than decrease the onset rate of dementia, but any net effect on severe dementia cannot be large in either direction.

We thank the British doctors some of whom have continued to collaborate in this prospective study of their health for almost half a century, Robert Clarke, Rory Collins, and Christina Davies for their comments, and Cathy Harwood and Gale Mead for preparing the manuscript.

Contributors: RD planned the study, IS has for many years conducted it, and RD, RP, and JB planned and conducted the present analyses. RD and RP prepared the report; they will act as guarantors for the paper.

Funding: The Medical Research Council has supported the study since 1951 and continues to do so through direct support of the Clinical Trial Service Unit and Epidemiological Studies Unit, helped by the Imperial Cancer Research Fund and British Heart Foundation.

Competing interests: None declared.

1 Baron JA. The beneficial effects of nicotine and cigarette smoking: the real, the possible, and the spurious. Brit Med Bull 1996;52:58-73.

2 Lee PN. Smoking and Alzheimer's disease. Neuroepidemiol 1994;13:13144 .

3 Doll R, Hill AB. Lung cancer and other causes of death in relation to smoking. A second report on the mortality of British doctors. BMJ 1956;2:1071-6.

4 Doll R, Peto R, Wheatley K, Gray R, Sutherland I. Mortality in relation to smoking: 40 years' observations on male British doctors. BMJ 1994:309:901-11.

5 Office of Population Censuses and Surveys. 1993 Mortality statistics:cause, England and Wales. London: HMSO, 1995:xi-v.

6 Launer LJ, Andersen K, Dewey ME, Letenneur L, Ott A, Amaducci LA, et al and the EURODERM Incidence Research Group and Work Groups. Rates and risk factors for dementia and Alzheimer's disease: results from EURODEM pooled analyses. Neurology 1999;52:78-84.
7 McKahnn G, Drachman D, Folstein M, Katzman R, Price D, Stadlan EM Clinical diagnosis of Alzheimer's disease: report of the NINCDS-ADRDA Work Group under the auspices of the Department of Health and Human Services Task Force on Alzheimer's disease. Neurology 1984:34:939-44.

8 Graves AB, Mortimer JA. Does smoking reduce the risk of Parkinson's and Alzheimer's diseases? J Smoking-related Dis 1994;5(suppl 1):79-90.

9 Braak H, Braak D, Yilmazer D, De Vos RAL, Jansen ENH, Bohl J. Pattern of brain destruction in Parkinson's and Alzheimer's diseases. J Neurol Transm 1996;103:455-90.

10 Jellinger KA. Morphological substrates of dementia in Parkinsonism. A critical update. J Neurol Transm 1997;51(suppl 1):57-82.

11 Hofman A, Rocca WA, Brayne C, Breteler MMB, Clarke M, Cooper B, et al for the EURODERM Prevalence Research Group. The prevalence of dementia in Europe: a collaborative study of 1980-90 findings. Int J Epidemiol 1991;20:736-47

12 Hirayama T. Large cohort study on the relation between cigarette smoking and senile dementia without cerebrovascular lesions. Tobacco Control 1992;1:176-9.

13 Yoshitake T, Kiohara Y, Kato I, Ohmura T, Iwamoto H, Nakayama K, et al. Incidence and risk factors of vascular dementia and Alzheimer's disease in a defined elderly Japanese population. Neurology 1995;45:1161-8.

14 Katzman R, Aronson M, Fuld P, Kawas C, Brown T, Morgenstern H, et al Development of dementing illness in an 80-year-old volunteer cohort Ann Neurol 1989;25:317-27.

15 Prince M, Cullen M, Mann A. Risk factors for Alzheimer's disease and dementia: a case-control study based on the MRC hypertension trial. Neurology 1994:44:97-104.

16 Merchant C, Tang M-X, Albert S, Manly J, Stern Y, Mayeux L. The influence of smoking on the risk of Alzheimer's disease. Neurology 1999;52:1408-12.

17 Hebert LE, Scherr PA, Beckett LA, Funkenstein HH, Albert MS, Chown MJ, et al. Relation of smoking and alcohol consumption to incident Alzheimer's disease. Am J Epidemiol 1992;135:347-55.

18 Wang H-X, Fratiolioni L, Frisoni GB, Vitanen M, Winblad B. Smoking and the occurrence of Alzheimer's disease: cross-sectional and longitudinal data in a population based study. Am J Epidemiol 1999;149:640-4.

19 Ott A, Slooter AJC, Hofman A, Van Harskamp F, Witteman JCM, Van Broeckhoven C, et al. Smoking and risk of dementia and Alzheimer's disease in a population-based cohort study. Lancet 1998;351:1840-3.

(2 January 2000)

\title{
Educational differences in smoking: international comparison
}

\author{
A E J M Cavelaars, A E Kunst, J J M Geurts, R Crialesi, L Grötvedt, U Helmert, E Lahelma, \\ O Lundberg, J Matheson, A Mielck, N Kr Rasmussen, E Regidor, M do Rosário-Giraldes, Th Spuhler, \\ J P Mackenbach
}

Department of

Public Health,

Erasmus University,

PO Box 1738,

$3000 \mathrm{DR}$

Rotterdam,

Netherlands

A E J M Cavelaars

research associate

A E Kunst

senior researcher

J P Mackenbach

professor

Statistics

Netherlands,

PO Box 4481,

6401 CZ Heerlen,

Netherlands

J J M Geurts

research associate

National Institute of Statistics, Servizio

Studi Metodologica,

00198 Rome, Italy

R Crialesi

senior researcher

continued over

BMJ 2000;320:1102-7

\begin{abstract}
Objective To investigate international variations in smoking associated with educational level.

Design International comparison of national health, or similar, surveys.

Subjects Men and women aged 20 to 44 years and 45 to 74 years.

Setting 12 European countries, around 1990.

Main outcome measures Relative differences (odds ratios) and absolute differences in the prevalence of ever smoking and current smoking for men and women in each age group by educational level. Results In the 45 to 74 year age group, higher rates of current and ever smoking among lower educated subjects were found in some countries only. Among women this was found in Great Britain, Norway, and Sweden, whereas an opposite pattern, with higher educated women smoking more, was found in southern Europe. Among men a similar north-south pattern was found but it was less noticeable than among women. In the 20 to 44 year age group, educational differences in smoking were generally
\end{abstract}

greater than in the older age group, and smoking rates were higher among lower educated people in most countries. Among younger women, a similar north-south pattern was found as among older women. Among younger men, large educational differences in smoking were found for northern European as well as for southern European countries, except for Portugal.

Conclusions These international variations in social gradients in smoking, which are likely to be related to differences between countries in their stage of the smoking epidemic, may have contributed to the socioeconomic differences in mortality from ischaemic heart disease being greater in northern European countries. The observed age patterns suggest that socioeconomic differences in diseases related to smoking will increase in the coming decades in many European countries.

\section{Introduction}

Socioeconomic inequalities in health have been found in all countries where data are available, and there is an 
Table 1 Characteristics of surveys

\begin{tabular}{|c|c|c|c|c|c|c|c|c|}
\hline Country & Year & Name & Sampling source & $\begin{array}{c}\text { Excluded } \\
\text { subpopulations }\end{array}$ & $\begin{array}{c}\mathrm{Nn}- \\
\text { response } \\
\text { rate (\%) }\end{array}$ & $\begin{array}{c}\text { No of } \\
\text { respondents } \\
\text { aged } 20-74 \\
\text { years }^{*}\end{array}$ & $\begin{array}{l}\text { Proportion } \\
(\%) \text { of } 20-74 \\
\text { years in } \\
\text { national } \\
\text { population }\end{array}$ & $\begin{array}{l}\text { Interview } \\
\text { method for } \\
\text { smoking } \\
\text { behaviour }\end{array}$ \\
\hline Denmark & 1986-7 & Danish health and morbidity survey & $\begin{array}{l}\text { Population } \\
\text { register }\end{array}$ & Foreigners & 20 & 4000 & 0.11 & Face to face \\
\hline Finland & $1990-1$ & $\begin{array}{l}\text { Health behaviour among the Finnish } \\
\text { adult population }\end{array}$ & $\begin{array}{l}\text { Population } \\
\text { register }\end{array}$ & $\begin{array}{l}\text { Institutionalised } \\
\text { people }\end{array}$ & 26 & 6700 & 0.19 & $\begin{array}{l}\text { Self } \\
\text { administered } \\
\text { questionnaire }\end{array}$ \\
\hline France & 1991 & $\begin{array}{l}\text { Enquête sur la santé et les soins } \\
\text { medicaux }\end{array}$ & $\begin{array}{l}\text { Population } \\
\text { register }\end{array}$ & $\begin{array}{l}\text { Institutionalised } \\
\text { people }\end{array}$ & 17 & 13400 & 0.04 & Face to face \\
\hline $\begin{array}{l}\text { West } \\
\text { Germany }\end{array}$ & $1988-91$ & Life and health in Germany & $\begin{array}{l}\text { Population } \\
\text { register }\end{array}$ & Foreigners & 30 & 10600 & 0.02 & $\begin{array}{l}\text { Self } \\
\text { administered } \\
\text { questionnaire }\end{array}$ \\
\hline Great Britain & $1990-1$ & General household survey & $\begin{array}{l}\text { Postal or address } \\
\text { files }\end{array}$ & $\begin{array}{l}\text { Institutionalised } \\
\text { people }\end{array}$ & 15 & 15000 & 0.04 & Face to face \\
\hline Italy & $1990-1$ & Multiple household survey & $\begin{array}{l}\text { Population } \\
\text { register }\end{array}$ & $\begin{array}{l}\text { Institutionalised } \\
\text { people }\end{array}$ & 11 & 37000 & 0.09 & Face to face \\
\hline Netherlands & $1991-2$ & Netherlands health interview survey & $\begin{array}{l}\text { Postal or address } \\
\text { files }\end{array}$ & $\begin{array}{l}\text { Institutionalised } \\
\text { people }\end{array}$ & 43 & 10200 & 0.10 & $\begin{array}{l}\text { Self } \\
\text { administered } \\
\text { questionnaire }\end{array}$ \\
\hline Norway & $1992-4$ & Multi purpose survey & $\begin{array}{l}\text { Population } \\
\text { register }\end{array}$ & $\begin{array}{l}\text { Institutionalised } \\
\text { people }\end{array}$ & 25 & 5000 & 0.18 & Face to face \\
\hline Portugal & 1987 & National health survey & $\begin{array}{l}\text { Population } \\
\text { register }\end{array}$ & $\begin{array}{l}\text { Institutionalised } \\
\text { people }\end{array}$ & 26 & 23700 & 0.36 & Face to face \\
\hline Spain & 1987 & National health survey & $\begin{array}{l}\text { Postal or address } \\
\text { files }\end{array}$ & $\begin{array}{l}\text { Institutionalised } \\
\text { people }\end{array}$ & 10 & 24900 & 0.10 & Face to face \\
\hline Sweden & 1991 & Swedish level of living survey & $\begin{array}{l}\text { Population } \\
\text { register }\end{array}$ & - & 21 & 4900 & 0.08 & Face to face \\
\hline Switzerland & $1992-3$ & Swiss health survey & $\begin{array}{l}\text { Telephone } \\
\text { directory }\end{array}$ & $\begin{array}{l}\text { Institutionalised } \\
\text { people }\end{array}$ & 29 & 13300 & 0.28 & Telephone \\
\hline
\end{tabular}

*Age limits for West Germany are 24 and 69 years; upper age limit for Finland is 64 years; lower age limit for Portugal is 25 years.

increasing interest in making international comparisons of their pattern and size. ${ }^{1-4}$ The results of these comparisons lead on to new questions about socioeconomic gradients in specific risk factors for disease, such as smoking.

Until now only a few studies have compared the magnitude of socioeconomic differences in smoking

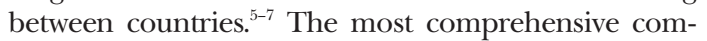
parison described differences in prevalence of smoking by educational level in the United Kingdom, Finland, Sweden, Norway, and France around $1987 .{ }^{6}$ In all these countries, lower educated people smoked more than higher educated people. The largest differences were observed in the United Kingdom and Norway. The international comparability of the data in this study was, however, not optimal. ${ }^{56}$

We compared socioeconomic differences in smoking in 12 European countries, including Denmark, Germany, the Netherlands, Switzerland, Portugal, Spain, and Italy. We assessed data from national health, or similar, surveys for 1986-94. To optimise the comparability of the data, we reanalysed original data sources and we reclassified the data according to standard specifications.

\section{Subjects and methods}

\section{Surveys and respondents}

Table 1 shows the data sources and some characteristics of the surveys. Mostly the data came from national health interview surveys, but in some countries data came from multipurpose or level of living surveys. Sampling procedures, non-response rates, and interview methods differed between countries. We restricted our analysis to respondents aged 20 to 74 years, ranging from 4000 respondents in Denmark to 37000 in
Italy. We analysed men and women and two age groups (20 to 44 and 45 to 74 years) separately.

We analysed the percentage of both people who ever smoked (current and former smokers) and people who were current smokers. As the percentage of people who were current cigarette smokers gave simithe percentage of current smokers, we decided to report on current smokers only.

\section{Educational level}

We chose educational level as an indicator of socioeconomic status. We did consider measuring educational level by years of education, but as this did not include the type and level of education and was not available for all the countries, we chose the highest level of education completed by the individual. In each country we regrouped educational levels according to a standard classification: 1 , no education completed; 2 , first level (primary school); 3, lower secondary level; 4, upper secondary level; and 5, tertiary level, which included university and other forms of education after the secondary level. ${ }^{8}$ We quantified educational differences in smoking in several ways, but as these provided similar results we decided to present the comparison of a "low educated" (levels 1-3) group with a "high educated" (levels 4 and 5) group, as these included all educational levels.

\section{Statistical analysis}

We used logistic regression analyses for each country to determine the differences in the percentage of current smokers and ever smokers between the two educational groups by sex and age group, with the high educational group as the reference group. To correct for age a nominal variable representing five year age groups was included in the regression model. Odds lar international patterns of inequalities in smoking as
Division for Health, Statistics Norway, PO Box 8131,

N 0033 Oslo 1,

Norway

L Grötvedt

senior registrar

Centre for Social

Policy Research,

Bremen University,

D-28209 Bremen,

Germany

senior researcher

Department of

Public Health,

University of

Helsinki,

PO Box 41, FIN

00014 Helsinki,

Finland

E Lahelma

professor

Swedish Institute

for Social Research,

Stockholm

University, 10691

Stockholm, Sweden

O Lundberg

senior researcher

Social Survey

Division, Office for

National Statistics,

Lonson

SW1V 2QQ

J Matheson

senior researcher

GSF-Institute for

Medical Informatics

and Health Service

Research,

PO Box 1129, D

85758 Neuherberg.

Germany

A Mielck

senior scientist

National Institute of

Public Health, 2100

Copenhagen,

Denmark

N Kr Rasmussen

deputy director

Department of

Epidemiology,

Ministry of Health,

28071 Madrid,

Span

E Regidor

epidemiologist

National School of Public Health, 1699 Lisbon, Portugal

$\mathrm{M}$ do

Rosário-Giraldes

professor

Swiss Federal

Statistical Office,

Espace de l'Europe

10, CH2010

Neuchâtel,

Switzerland

Th Spuhler

head of health section

Corresponding

author:

J P Mackenbach

mackenbach@mgz.

fgg.eur.nl 
Table 2 Prevalence of smoking among men from 12 European countries and differences between low and high educational levels (high educated group is reference category)

\begin{tabular}{|c|c|c|c|c|c|c|c|c|}
\hline \multirow[b]{3}{*}{ Country } & \multicolumn{4}{|c|}{ Age group (20-44 years) } & \multicolumn{4}{|c|}{ Age group (45-74 years) } \\
\hline & \multicolumn{2}{|r|}{ Ever smoking } & \multicolumn{2}{|c|}{ Current smoking } & \multicolumn{2}{|r|}{ Ever smoking } & \multicolumn{2}{|c|}{ Current smoking } \\
\hline & $\%$ & Odds ratio $(95 \% \mathrm{CI})$ & $\%$ & Odds ratio $(95 \% \mathrm{Cl})$ & $\%$ & Odds ratio $(95 \% \mathrm{CI})$ & $\%$ & Odds ratio $(95 \% \mathrm{CI})$ \\
\hline Denmark & 64.7 & 0.94 (0.64 to 1.38$)$ & 50.0 & 1.34 (0.94 to 1.91$)$ & 85.1 & 1.11 (0.74 to 1.67$)$ & 55.2 & 1.06 (0.79 to 1.43$)$ \\
\hline Finland & 70.2 & 1.68 (1.27 to 2.22) & 47.1 & 1.57 (1.24 to 1.98) & 73.1 & $1.02(0.78$ to 1.34$)$ & 36.1 & 1.00 (0.78 to 1.29$)$ \\
\hline France & 66.6 & 2.27 (1.96 to 2.63$)$ & 48.0 & 2.32 (2.01 to 2.68 ) & 71.6 & $1.02(0.84$ to 1.25$)$ & 31.2 & 1.19 (0.97 to 1.45$)$ \\
\hline West Germany & 71.7 & 1.51 (1.24 to 1.82$)$ & 48.8 & 1.56 (1.32 to 1.85$)$ & 74.9 & 1.31 (1.08 to 1.58$)$ & 34.8 & 1.50 (1.27 to 1.78$)$ \\
\hline Great Britain & 58.9 & 2.01 (1.71 to 2.37 ) & 42.2 & 2.26 (1.94 to 2.64$)$ & 78.4 & 1.58 (1.31 to 1.89 ) & 36.5 & 1.74 (1.47 to 2.05 ) \\
\hline Italy & 57.3 & 1.69 (1.56 to 1.83$)$ & 44.3 & 1.69 (1.56 to 1.82$)$ & 71.1 & $1.11(0.98$ to 1.26$)$ & 37.8 & 1.09 (0.97 to 1.23$)$ \\
\hline Netherlands & 69.1 & 1.66 (1.39 to 1.99) & 46.3 & 1.81 (1.55 to 2.12 ) & 88.1 & 1.25 (0.95 to 1.64) & 42.7 & 1.21 (1.02 to 1.45$)$ \\
\hline Norway & 59.7 & 2.71 (2.12 to 3.46$)$ & 40.0 & 2.87 (2.28 to 3.60$)$ & 75.5 & $1.39(1.05$ to 1.84$)$ & 34.7 & 1.73 (1.33 to 2.24$)$ \\
\hline Portugal & 62.0 & 0.70 (0.61 to 0.81$)$ & 47.2 & 0.80 (0.70 to 0.91$)$ & 54.2 & 0.51 (0.43 to 0.61$)$ & 27.7 & 0.65 (0.54 to 0.77 ) \\
\hline Spain & 75.4 & 1.43 (1.26 to 1.62) & 64.2 & 1.54 (1.37 to 1.72$)$ & 75.9 & 0.94 (0.77 to 1.14$)$ & 48.9 & 0.97 (0.82 to 1.15$)$ \\
\hline Sweden & 51.4 & 2.52 (1.94 to 3.27$)$ & 31.9 & 2.59 (2.00 to 3.34$)$ & 68.7 & $1.08(0.84$ to 1.40$)$ & 30.3 & 1.50 (1.15 to 1.96$)$ \\
\hline Switzerland & 57.7 & 1.35 (1.09 to 1.66$)$ & 42.0 & 1.23 (1.01 to 1.51$)$ & 72.0 & 1.13 (0.91 to 1.42$)$ & 33.7 & 1.31 (1.06 to 1.61$)$ \\
\hline Total & 63.6 & 1.54 (1.47 to 1.65$)$ & 47.5 & 1.65 (1.58 to 1.72$)$ & 71.2 & 1.05 (0.99 to 1.11) & 36.9 & 1.18 (1.12 to 1.25$)$ \\
\hline Education $v$ country & & $\mathrm{P}<0.001$ & & $P<0.001$ & & $\mathrm{P}<0.001$ & & $\mathrm{P}<0.00$ \\
\hline
\end{tabular}

ratios and $95 \%$ confidence intervals were calculated from the regression coefficients and their standard errors. To test whether odds ratios varied significantly between countries we performed additional analyses for all countries combined, including terms representing the interaction between education and country.

The proportion of men and women in the low educated group was higher in France, Italy, Spain, and Portugal than in the other countries. To avoid comparisons of the odds ratios between the countries being affected by variations in the size of the educational groups, we also calculated the relative index of inequality. ${ }^{9-11}$ In this index all educational levels are taken into account separately, with an adjustment for the size of the educational groups. Generally the estimates of relative index of inequality showed the same international patterns as the odds ratios on the basis of the two educational groups; the correlation between the two indices was generally high $(\mathrm{r}>0.9, \mathrm{P}<0.01)$. Because of the high correspondence between the two inequality indices, we present only the simpler odds ratio.

Absolute rate differences were added to the odds ratios because they take into account differences between countries in the overall prevalence of smoking. Absolute differences were calculated by subtracting the prevalence rate of smoking in the higher educated group from that of the lower one. To correct for differences in age between the educational groups we used indirect standardisation for each country and sex.

\section{Results}

Relative differences among men

Table 2 shows the average prevalence rates of smoking and the relative differences in smoking between educational groups among men. The proportion of current smokers ranged from 32\%-64\% among the younger men, and from $28 \%-55 \%$ among the older men. The proportion of current smokers was generally lower than that of ever smokers, suggesting a sizeable group of ex-smokers.

Most odds ratios for current smoking were greater than 1.00, indicating a higher prevalence of smoking in the lower educated group. The odds ratios were usually higher among the younger than older men. The highest odds ratios among younger men were observed in Norway, Sweden, France, and Great Britain whereas among older men the highest odds ratios were observed in Great Britain and Norway. The only odds ratios that were clearly less than 1.00 were observed in

Table 3 Prevalence of smoking among women from 12 European countries and differences between low and high educational levels (high educated group is reference category)

\begin{tabular}{|c|c|c|c|c|c|c|c|c|}
\hline \multirow[b]{3}{*}{ Country } & \multicolumn{4}{|c|}{ Age group (20-44 years) } & \multicolumn{4}{|c|}{ Age group (45-74 years) } \\
\hline & \multicolumn{2}{|r|}{ Ever smoking } & \multicolumn{2}{|c|}{ Current smoking } & \multicolumn{2}{|r|}{ Ever smoking } & \multicolumn{2}{|c|}{ Current smoking } \\
\hline & $\%$ & Odds ratio $(95 \% \mathrm{CI})$ & $\%$ & Odds ratio $(95 \% \mathrm{CI})$ & $\%$ & Odds ratio $(95 \% \mathrm{CI})$ & $\%$ & Odds ratio $(95 \% \mathrm{CI})$ \\
\hline Denmark & 61.2 & $1.27(0.85$ to 1.90$)$ & 49.1 & 1.28 (0.87 to 1.89$)$ & 65.9 & 1.14 (0.84 to 1.48$)$ & 45.3 & $1.20(0.89$ to 1.60$)$ \\
\hline Finland & 59.0 & 1.64 (1.29 to 2.09$)$ & 33.5 & 1.93 (1.53 to 2.44$)$ & 35.8 & $0.80(0.63$ to 1.02$)$ & 18.7 & $1.14(0.85$ to 1.52$)$ \\
\hline France & 46.6 & $1.10(0.96$ to 1.26$)$ & 31.2 & 1.36 (1.18 to 1.58$)$ & 18.3 & 0.42 (0.34 to 0.52$)$ & 9.9 & 0.61 (0.46 to 0.81$)$ \\
\hline Italy & 33.5 & 0.99 (0.91 to 1.08$)$ & 25.5 & 1.10 (1.01 to 1.21$)$ & 19.9 & 0.37 (0.32 to 0.43$)$ & 13.3 & 0.46 (0.39 to 0.54$)$ \\
\hline Netherlands & 67.2 & 1.58 (1.33 to 1.87$)$ & 41.1 & $1.67(1.43$ to 1.94$)$ & 51.4 & $0.75(0.62$ to 0.90$)$ & 24.2 & $1.37(1.10$ to 1.70$)$ \\
\hline Norway & 58.2 & 3.21 (2.53 to 4.11$)$ & 37.5 & 2.64 (2.09 to 3.34$)$ & 51.4 & 1.84 (1.37 to 2.48 ) & 28.9 & 2.73 (1.90 to 3.93$)$ \\
\hline West Germany & 60.4 & 1.25 (1.04 to 1.51$)$ & 39.0 & 1.52 (1.26 to 1.82$)$ & 34.1 & 0.63 (0.53 to 0.73$)$ & 18.5 & 0.98 (0.81 to 1.20$)$ \\
\hline Great Britain & 49.4 & 2.04 (1.78 to 2.34$)$ & 34.6 & 2.50 (2.17 to 2.89 ) & 51.4 & 1.58 (1.34 to 1.86$)$ & 27.6 & 2.07 (1.70 to 2.51 ) \\
\hline Portugal & 12.5 & 0.12 (0.10 to 0.15$)$ & 9.1 & $0.13(0.11$ to 0.17$)$ & 2.2 & 0.06 (0.04 to 0.08$)$ & 1.4 & 0.05 (0.04 to 0.09$)$ \\
\hline Spain & 48.1 & 0.53 (0.47 to 0.60$)$ & 39.7 & 0.57 (0.50 to 0.64$)$ & 6.5 & 0.22 (0.16 to 0.29$)$ & 3.9 & 0.29 (0.20 to 0.42$)$ \\
\hline Sweden & 55.3 & 2.37 (1.82 to 3.09 ) & 33.2 & 2.34 (1.81 to 3.03 ) & 45.9 & 1.22 (0.94 to 1.56$)$ & 26.7 & 1.41 (1.06 to 1.87$)$ \\
\hline Switzerland & 50.8 & 1.24 (1.04 to 1.48$)$ & 32.5 & 1.50 (1.26 to 1.80$)$ & 35.5 & $0.89(0.76$ to 1.04$)$ & 18.7 & $1.16(0.96$ to 1.40$)$ \\
\hline Total & 46.2 & $1.02(0.98$ to 1.07$)$ & 31.0 & 1.18 (1.13 to 1.24$)$ & 23.9 & 0.69 (0.65 to 0.73$)$ & 13.5 & 0.99 (0.92 to 1.06$)$ \\
\hline Education $v$ country & & $P<0.001$ & & $P<0.001$ & & $\mathrm{P}<0.001$ & & $P<0.001$ \\
\hline
\end{tabular}


Portugal where smoking was more prevalent in the higher educated group among both groups of men.

The odds ratios for ever smoking tended to be slightly lower than those for current smoking, implying that educational differences in smoking are not only the result of differences in uptake of smoking but also of a higher rate of quitting among the higher educated groups.

\section{Relative differences among women}

The percentage of current smokers among women was generally lower than that among men, particularly in the older age group (table 3). In Spain and Portugal less than $5 \%$ of older women were current smokers.

In most countries the social gradient of current smoking was as clear among younger women as it was among younger men. The highest odds ratios were found in Norway, Sweden, and Great Britain, and the only odds ratios less than 1.00 were found in Spain and Portugal. Among older women the highest odds ratios were again found in Norway and Great Britain, but here there are more countries than for younger women (and for older men) where smoking is more prevalent in the higher educated groups and therefore the odds ratios are less than 1.00: this is the case in France, Italy, Spain, and Portugal.

\section{Absolute differences}

The figure shows the absolute difference in current smoking between educational levels, by sex and age group. These differences showed the same international patterns as the odds ratios. A high correspondence between absolute and relative measures was also observed for ever smoking (results not shown).

\section{Discussion}

\section{Evaluation of data problems}

A potential problem relates to the accuracy of survey estimates of prevalence rates of smoking. Nonresponse and the use of self reports to measure smoking probably led to an underestimation of national prevalence rates of smoking. ${ }^{12}{ }^{13}$ The international patterns reported here, however, will only be biased when this underestimation is associated with education and when countries vary in the strength of this association. A Swedish study investigated the effect of nonresponse $(37 \%)$ in a health survey on socioeconomic differences in smoking. ${ }^{14}$ Despite large differences in smoking rates between respondents and nonrespondents, socioeconomic differences in smoking were not substantially or consistently underestimated or overestimated. Non-response is therefore unlikely to have had a major effect on our results. A few other studies have investigated whether underreporting of smoking is related to socioeconomic status. No association was found between underreporting and socioeconomic status among middle aged Danish men. ${ }^{15} \mathrm{~A}$ higher rate of underreporting of smoking, however, was found among lower educated men and women in the United States, ${ }^{16}$ whereas a US study among immigrants from south east Asia found an association for women but not for men. ${ }^{17}$ These inconsistent results seem to imply that the association between education and underreporting varies between countries,

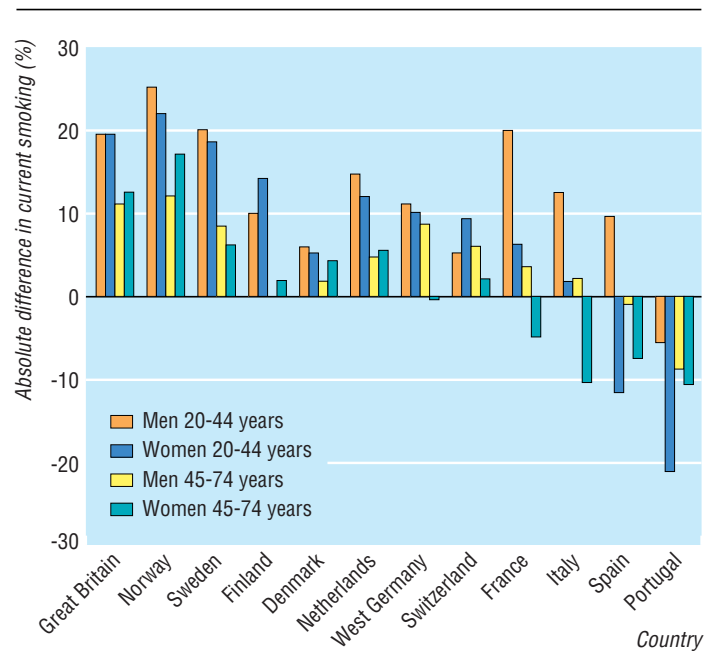

Absolute differences in current smoking between low and high educated men and women aged 20-44 and 45-74 years

men and women, and perhaps over time, possibly due to variations in social norms concerning smoking. Therefore we cannot exclude the possibility that the international position of some countries is biased as a result of the use of self reports to measure smoking. The available evidence, however, does not suggest that the pronounced international patterns we observed can be explained completely in this way.

Other potential problems relate to international differences in sampling, interview method, and questions used to measure smoking behaviour. However, the effect of these differences on the international patterns reported is probably marginal as the differences in smoking corresponded well with the estimates we obtained by using an international data source, with similar procedures, methods, and questions for all countries. ${ }^{18}$

\section{Results of other studies}

Our results agree well with those of national studies of other data sources of the same period as our study. For example, studies from southern Europe found weak associations between socioeconomic status and smoking among women. ${ }^{19-22}$

The results of a previous international comparison should be interpreted with caution both because the educational classifications differed between countries and because information on the comparability of the smoking data and study populations was lacking. ${ }^{5}$ Nevertheless, comparatively large differences in smoking were found in Great Britain and Norway and smaller differences in Finland. In contrast to our study, however, comparatively small differences were found for men and women from Sweden.

In another study, we calculated educational differences in current smoking for men and women aged 20-74 years, with data from the international Eurobarometer survey. ${ }^{23}$ The procedures, methods, and questions from this survey are highly comparable between countries but it has several disadvantages: a higher non-response rate, a smaller number of respondents per country, and a lack of data on most Nordic countries. For the remaining countries, however, the results corresponded well to those for the two age groups combined in our study. The Eurobarometer data 
What is already known on this topic

Smoking is more prevalent in the lower than higher socioeconomic groups, particularly in northern European countries such as the United Kingdom

Previous studies have suggested that there may be international variations in these differences in smoking, but these were comparatively smallscale studies without much attention to comparability of data between countries

\section{What this study adds}

In most countries smoking is more prevalent among the lower educated, although there are important international variations

A north-south pattern, with strong gradients in northern European countries and weaker or reversed gradients in southern European countries, was found for women and to a lesser extent for men in the 45-74 year age group but not for younger men

Smoking differences were larger among younger than older people in most countries

also showed a north-south pattern for women and comparatively small differences among men from Denmark compared with Great Britain. A comparatively large discrepancy was found only between the results for young men from France, for whom the Eurobarometer data showed much smaller differences than the national survey used in our current study.

\section{The smoking epidemic}

Several studies have shown that smoking spreads through populations like an epidemic with four stages. $^{24} 25$ In stage 1 , smoking is an exceptional behaviour and mainly a habit of higher socioeconomic groups. In stage 2, smoking becomes ever more common. Rates among men peak at 50\%-80\% and are equal among socioeconomic groups or higher among higher socioeconomic groups. In women these patterns usually lag 10-20 years behind those of men. Smoking is first adopted by women from higher socioeconomic groups. In stage 3, prevalence rates among men decrease to about $40 \%$ since many men stop smoking, especially those who are better off. Women reach their peak rate (35\%-45\%) during this stage, and at the end of this stage their rates start to decline too. In stage 4 , prevalence rates keep declining slowly for both men and women, and smoking becomes progressively more a habit of the lower socioeconomic groups. During the smoking epidemic there is a reversal from a positive to a negative association between socioeconomic status and smoking.

On the basis of national prevalence rates for smoking for men and women it has been hypothesised that countries in southern Europe are in stage 2 (Portugal) or at the beginning of stage 3 (Spain, Italy, France) of the smoking epidemic, whereas northern European countries are at the end of stage 3 or in stage $4 .{ }^{25}$ Our findings on educational differences in smoking, with "reverse" smoking gradients among women in southern Europe and strong smoking gradients among both men and women in northern Europe, support this hypothesis.

\section{Implications}

Our study has several implications, both for the explanation of socioeconomic inequalities in health and for policies directed towards reducing socioeconomic inequalities in health. Smoking is an important risk factor for disease, and it would therefore be expected that socioeconomic inequalities in health are greater in countries with greater inequalities in smoking, particularly for diseases linked to smoking. An analysis of differences in cause specific mortality by occupational class for middle aged men partly confirms this. ${ }^{4}$ This study found large differences in ischaemic heart disease in Great Britain and the Nordic countries and small differences in Switzerland, France, and more southern European countries. This pattern is largely consistent with the north-south pattern we found for differences in smoking behaviour among men aged $45-74$ years. We found a significant positive association between differences in ischaemic heart disease and differences in current $(\mathrm{r}=0.65, \mathrm{P}=0.06)$ and ever smoking $(\mathrm{r}=0.76$, $\mathrm{P}=0.02)$. Large differences in lung cancer were observed in northern European countries, particularly Finland, and the southern European countries. ${ }^{4}$ An exception was Portugal for which no differences were observed. The findings from Portugal are in accordance with our results for smoking, but overall there are no strong associations between the differences in lung cancer and differences in current $(r=0.22, \mathrm{P}=0.57)$ and ever smoking $(\mathrm{r}=0.38, \mathrm{P}=0.31)$. A possible explanation for the lack of a clear association is that our smoking data do not give an accurate estimate of life time exposure to smoking in the age groups.

Our study also has several implications for policy. Firstly, socioeconomic inequalities in morbidity and mortality related to smoking are likely to increase in the future, and therefore a reduction of inequalities in health will require powerful policies. Most studies of socioeconomic inequalities in mortality deal with middle aged men and, occasionally, women. Our results show that social gradients in smoking are steeper in younger men and women than in these older generations (tables 2 and 3), and it is likely that these steeper gradients of smoking will translate into steeper gradients in morbidity and mortality related to smoking in the future. This applies to all countries in this study, but perhaps more to southern European countries where the current small or even reversed inequalities in mortality from ischaemic heart disease may develop into patterns similar to those in northern Europe. ${ }^{4}$

How can socioeconomic inequalities in smoking be reduced? It is likely that they have arisen partly as a result of health education efforts: due to the largely cognitive nature of conventional health education and its dependence on voluntary behavioural change, it will have had a larger effect on higher educated people. A major priority for public health should be the development of antismoking policies and interventions, which are effective in low socioeconomic groups, perhaps using pricing policies and community based approaches.

We thank the national statistical offices of all participating countries for providing unpublished data from their national surveys, the National Public Health Institute of Finland for data from the 
health behaviour monitoring survey among the Finnish adult population, 1990-1. Material from the general household survey, 1990-1, is Crown copyright; it has been made available by the Office for National Statistics through the data archive and has been used with permission. Data from the Enquête sur la Santé et les Soins Medicaux were provided by Mr and Mrs Mizrahi (Centre de Recherche, d'Etude et de Documentation en Economie de la Santé, France). None of these institutions bear any responsibility for the analysis or interpretation of the data reported here. This study is part of a larger project on socioeconomic inequalities in morbidity and mortality, which is conducted within the framework of a concerted action sponsored by the European Union. The design of the project, the data specifications, and the interpretation of preliminary results were discussed at three workshops.

Contributors: AEJMC organised data collection, carried out the analysis, and wrote a first version of this paper. AEK supervised data collection and analysis and helped in interpreting the data and writing the paper. JPM designed the study, helped in interpreting the data, and wrote the final version of this paper. He will act as guarantor for the paper. The other coauthors collected the data for their own country, helped in interpreting these data, and commented on the paper.

Funding: This study was supported by a grant from the

European Union's Biomed-1 program (CT92-1068).

Conflict of interest: None declared.

1 Vågerö D, Lundberg O. Health inequalities in Britain and Sweden. Lancet 1989;ii:35-6.

2 Van Doorslaer E, Wagstaff A, Bleichrodt H, Burg vdH, Calonge S, Gerdtham U, et al. Income-related inequalities in health: some international comparisons. J Health Econ 1997;16:93-112.

3 Mackenbach JP, Kunst AE, Cavelaars AEJM, Groenhof F, Geurts JIM, EU-Working Group on Socioeconomic Inequalities in Health. Socioeconomic inequalities in morbidity and mortality in Western Europe: a comparative study. Lancet 1997;349:1655-9.

4 Kunst AE, Groenhof F, Mackenbach JP and the EU Working Group on Socioeconomic Inequalities in Health. Occupational class and causespecific mortality in middle aged men in 11 European countries: a comparison of population based studies. BMJ 1998;316:1636-41.

5 Pierce JP. International comparisons of trends in cigarette smoking prevalence. Am J Public Health 1989;79:152-7.

6 Pierce JP. Progress and problems in international public health efforts to reduce tobacco usage. Annu Rev Publ Health 1991;12:383-400.

7 Helmert U, Mielck A, Classen E. Social inequities in cardiovascular disease risk factors in East and West Germany. Soc Sci Med 1992;35; $1283-92$
8 Organization for Economic Co-operation and Development. Education in OECD countries 1987-89. A compendium of statistical information. Paris: OECD, 1990

9 Pamuk ER. Social class and inequality in mortality from 1921 to 1972 in England and Wales. Popul Stud 1985;39:17-31.

10 Kunst AE, Mackenbach JP. Measuring socio-economic inequalities in health Copenhagen: World Health Organisation, 1994.

11 Mackenbach JP, Kunst AE. Measuring the magnitude of socio-economic inequalities in health: an overview of available measures illustrated with two examples from Europe. Soc Sci Med 1997;44:757-71.

12 Patrick DL, Cheadle A, Thompson DC, Diehr P, Koepsell T, Kinne S. The validity of self-reported smoking: a review and meta-analysis. Am J Public Health 1994:84:1086-93.

13 Todd GF. Cigarette consumption per adult of each sex in various countries. J Epidemiol Community Health 1978;32:289-93.

14 Boström G, Hallqvist J, Haglund BJA, Romelsjö A, Svanström L, Diderichsen F. Socioeconomic differences in smoking in an urban Swedish population. The bias introduced by non-participation in a mailed questionnaire. Scand J Soc Med 1993;21:77-82.

15 Suadicani P, Hein HO, Gyntelberg F. Serum validated tobacco use and social inequalities in risk of ischaemic heart disease. Int J Epidemiol 1994;23:293-300

16 Wagenknecht LE, Burke GL, Perkins LL, Haley NJ, Friedman GD. Misclassification of smoking status in the CARDIA study: A comparison of self-report with serum cotinine levels. Am J Public Health 1992;82:33-6.

17 Wewers ME, Dhatt RK, Moeschberger ML, Gurthrie RM, Kuun P, Chen MS. Misclassification of smoking status among Southeast Asian adult immigrants. Am J Respir Crit Care Med 1995;152:1917-21.

18 Kunst AE, Cavelaars AEJM, Groenhof F, Geurts JJM, Mackenbach JP, EU-Working Group on Socioeconomic Inequalities in Health. Socioeconomic inequalities in morbidity and mortality in Europe: a comparative study. Rotterdam: Erasmus University, 1996.

19 Ferraroni M, La Vecchia C, Pagano R, Negri E, Decarli A. Smoking in Italy, 1986-1987. Tumori 1989;75:521-6.

20 La Vecchia C, Gutzwiller F, Wietlisbach V. Sociocultural influences on smoking habits in Switzerland. Int J Epidemiol 1987;16:624-6.

21 Berrino F, Merletti F, Zubiri A, Del Moral A, Raymond L, Esteve J, et al. A comparative study of smoking, drinking and dietary habits in population samples in France, Italy, Spain and Switzerland. II Tobacco smoking. Rev Epidém et Santé Publ 1988:36:166-76.

22 Sasco AJ, Grizeau D, Pobel C, Chatard O, Danzon M. Tabagisme et classe sociale en France de 1974 à 1991. Bulletin Cancer 1994;81:355-9.

23 Cavelaars AEJM, Kunst AE, Mackenbach JP. Socio-economic difference in risk factors for morbidity and mortality in the European Community: an international comparison. J Health Psychol 1997;2:353-72.

24 Peto R, Lopez AD, Boreham J, Thun M, Heath C. Mortality from smoking in developed countries 1950-2000: indirect estimates from national vital statistics. Oxford: Oxford University Press, 1994.

25 Graham H. Smoking prevalence among women in the European community 1950-1990. Soc Sci Med 1996;43:243-54.

(Accepted 2 January 2000)

\title{
Evaluating "payback" on biomedical research from papers cited in clinical guidelines: applied bibliometric study
}

\author{
Jonathan Grant, Robert Cottrell, Françoise Cluzeau, Gail Fawcett
}

\begin{abstract}
Objectives To develop a methodology for evaluating the impact of research on health care, and to characterise the papers cited on clinical guidelines. Design The bibliographic details of the papers cited in 15 clinical guidelines, developed in and for the United Kingdom, were collated and analysed with applied bibliometric techniques.

Results The median age of papers cited in clinical guidelines was eight years; most papers were published by authors living in either the United States $(36 \%)$ or the United Kingdom (25\%)-this is two and a half times more than expected as about $10 \%$ of all biomedical outputs are published in the United Kingdom; and clinical guidelines do not cite basic research papers.

Conclusion Analysis of the evidence base of clinical guidelines may be one way of tracking the flow of knowledge from the laboratory to the clinic.
\end{abstract}

Moreover, such analysis provides a useful, clinically relevant method for evaluating research outcomes and different strategies in research and development.

\section{Introduction}

The United Kingdom spends over $£ 1600$ million a year on non-commercial biomedical and health services research. ${ }^{1}$ This research is funded either from the public purse, such as the NHS and the Medical Research Council, or medical research charities, such as the Wellcome Trust. The tacit understanding is that the biomedical research these bodies support will lead to an eventual improvement in health. The system is highly complex, however, and medical agencies support a wide spectrum of activity from basic biomedical research through to research in health services and assessments of technology. Notwithstanding this complexity, there is a need to understand how
Policy Unit, Wellcome Trust, London NW1 2BE

Jonathan Grant policy advisor

Robert Cottrell policy officer

Gail Fawcett policy officer

Health Care Evaluation Unit, St George's Hospital Medical School, London SW17 0RE

Françoise Cluzeau lecturer in health services

Correspondence to: J Grant j.grant@wellcome. ac.uk

BMJ 2000;320:1107-11 